\title{
Kinetic and Activation Thermodynamic Studies on the Decay of Organic Peroxides in $\gamma$ - irradiation of Threonine in Aqueous Solutions at Different pH's
}

\author{
Azhar A.A Al-Obaidy $\quad$ Emad A. S. Al-Hyali \\ Department of Chemistry / College of Education \\ University of Mosul
}

Rana H. A. K. Al-Hyali

Department of Chemistry / College of Science

University of Mosul

Received

$07 / 10 / 2010$
Accepted

17 / 02 / 2011

\begin{abstract}
الخلاصة
أجريت دراسات حركية وثيرموداينميكية على انحلال البيروكسيدات العضوية المتكونة

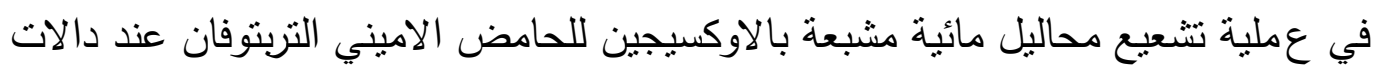

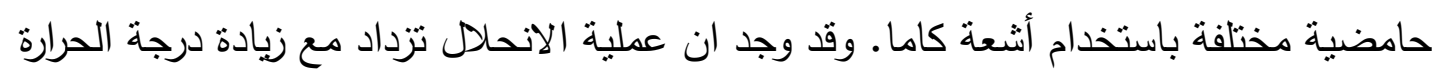
والدالة الحامضية ـ القياسات الثيرموداينميكية توضح إن الانحلال غير تلقائي وان درجة الحرارة

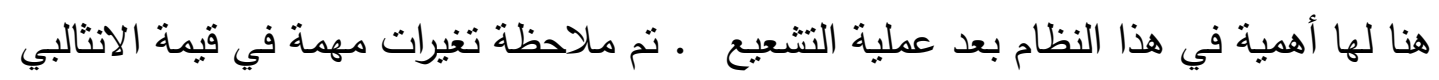

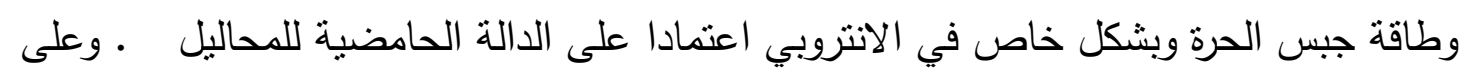
ضوء هذه النتائج تم اقتراح آلية مناسبة لتنكك البيروكسيدات العضوية التروبي اعبد الدراسة.
\end{abstract}

\begin{abstract}
Rate constants and thermodynamic studies have been performed on the decay of threonine amino acid peroxides produced from $\gamma$ - irradiation of aqueous oxygenated solutions at different pH's. The decay was found to follow first order kinetic.

The rate of decomposition increases by increasing temperature and $\mathrm{pH}$ of irradiated solutions. The activation thermodynamic measurements illustrate that, the decay of threonine amino acid peroxides is not spontaneously, and thus, it can be concluded that, the temperature here
\end{abstract}


has important effect on post irradiation in this system. Significant change in values of $\Delta \mathrm{H}^{*}, \Delta \mathrm{G}^{*}$ and specially $\Delta \mathrm{S}^{*}$ were observed depending on $\mathrm{pH}$ of irradiated solutions. On the view of the obtained results, a proper mechanism for decomposition was suggested.

Key words: $\gamma$-irradiation, Kinetic study, Threonine.

\section{Introduction}

Radiation chemistry of amino acids is been considered one of the most important studies in the field of radiobiology. Many radiation chemists studied amino acids ${ }^{(1,2)}$. They have found that, the attachment of the active species on amino acid molecule by abstracting the hydrogen atom $\alpha$-carbon and / or $\beta$-carbon in acidic medium and / or NH group in basic medium are generally the main reactions. Attack may also occur at other sites with more complex amino acids ${ }^{(3,4)}$.

Many workers ${ }^{(5-7)}$ have studied radiolysis of aqueous oxygenated solutions of many amino acids.

It was reported ${ }^{(8,9)}$ that, organic peroxides are always produced at different $\mathrm{pH}$ conditions. Decay of these organic peroxides was followed. The formation and decomposition of organic peroxides indicating the role of oxygen in radio sensitization in biological system, which took a great attention. Thus, the kinetic and activation thermodynamic studies to explain the organic peroxides decomposition, become more necessary.

\section{a- Material:}

\section{Experimental}

All materials used during irradiation were of analytical grade including materials used to determine the dose rate.

Threonine and other compounds such as ammonium molybdate, potassium iodide and potassium hydrogen phthalate used for peroxide determination without further purification and were supplied from Sigma chemical Ltd.

\section{b- Preparation and Irradiations of Solutions :}

All solutions were prepared using freshly triple-distilled water. The ordinary distillation was followed by another distillation from alkaline potassium permanganate solution, then redistilled ordinary once again to obtain triply - distilled water with conductivity not more than 3 $\times 10^{-6} \mathrm{ohm}^{-1} \mathrm{~cm}^{-1}$.

The freshly prepared oxygenated threonine solutions were irradiated using gamma cell-220 purchased from Canadian Atomic Energy. The source consists of a number of Co-60 rods.

All spectrophotometric measurements were carried out using Shimadzu U.V. visible Recording Spectrophotometer. U.V 160. 
The $\mathrm{pH}$ measurements were performed on Philips P W 9420 meter. Buffer solutions were used to control the $\mathrm{pH}$ of the studied medium. The dose rate used was $4.5 \times 10^{16} \mathrm{ev} \mathrm{ml}^{-1} \mathrm{~min}^{-1}$.

\section{c- Determination of peroxides :}

Total peroxides (TP) include organic peroxide (OP) and $\mathrm{H}_{2} \mathrm{O}_{2}$. The most widely used method for determination of peroxides (TP) in aqueous solutions is the iodide method, which is based on that of Allen et. al., ${ }^{(10)}$.It involves the oxidation of potassium iodide by $\mathrm{H}_{2} \mathrm{O}_{2}$ and organic peroxide materials in the presence of ammonium molybdate as catalysts.

The librated iodine is determined spectrophotometrically as $\mathrm{I}_{3}{ }^{-}$at $352 \mathrm{~nm}$

$\varepsilon=2.4 \times 10^{3} \mathrm{dm}^{3} \mathrm{~mol}^{-1} \mathrm{~cm}^{-1}$. method) ${ }^{(11)}$.

$\mathrm{H}_{2} \mathrm{O}_{2}$ is determined directly by Tinder method (peroxidase

This method based on the reaction of $\mathrm{H}_{2} \mathrm{O}_{2}$ with 4-amino antipyrine -phenol in the presence of peroxidase as catalyst.

\section{Results and Discussion}

Gamma radiolysis of threonine $\left(2 \times 10^{-3} \mathrm{M}\right)$ in aqueous oxygenated solutions has been studied at different $\mathrm{pH}$.

The peroxides (organic peroxide compounds and $\mathrm{H}_{2} \mathrm{O}_{2}$ ) produced due to irradiation have been estimated.The results obtained are summarized in Table (1) which are indeed well agree with those reported previously ${ }^{(1,2)}$.

Table (1)

Determination of amount of peroxides produced by $\gamma$-irradiation of aqueous solution of threonine $\left(2 \times 10^{-3} \mathrm{M}\right)$ at different $\mathrm{pH}$ 's.

\begin{tabular}{||c|c|c|c||}
\hline \hline $\mathbf{p H}$ & $\mathbf{G}_{\mathbf{T P}}$ & $\mathrm{G}_{\mathrm{H}_{2} \mathrm{O}_{2}}$ & $\mathbf{G}_{\mathbf{O} . \mathbf{P}}$ \\
\hline 3 & 2.41 & 1.05 & 1.34 \\
\hline 5.7 & 2.30 & 0.80 & 1.50 \\
\hline 7 & 1.87 & 0.85 & 1.02 \\
\hline 9 & 2.10 & 0.70 & 1.40 \\
\hline 11 & 2.05 & 0.87 & 1.18 \\
\hline
\end{tabular}

Decay of organic peroxide materials, produced by $\gamma$ - irradiation, for 35 minutes, has been investigated and it has been found that, only organic peroxides beer decay over 60 minutes at that different $\mathrm{pH}$ 's and temperatures used, while $\mathrm{H}_{2} \mathrm{O}_{2}$ almost seemed to be stable during this time (60 minutes). Thus, the observed decomposition, in fact, related to the threonine amino acids organic peroxides. The percentages of decay of threonine at different $\mathrm{pH}$ 's and temperatures are listed in Table (2). 
Kinetic and Activation Thermodynamic Studies on the Decay of Organic ...

Table (2)

Effect of temperatures and pH's on the decay of oxygenated solutions of organic peroxides of threonine.

\begin{tabular}{|c|c|c|c|c|c|}
\hline \multirow{2}{*}{ pH } & \multirow{2}{*}{$\begin{array}{l}\text { Time of } \\
\text { irradiation } \\
(\text { min })\end{array}$} & \multicolumn{4}{|c|}{$\%$ of decay at temperature } \\
\hline & & $20 \mathrm{C}^{\mathrm{o}}$ & $25 \mathrm{C}^{\mathrm{o}}$ & $30 \mathrm{C}^{\mathbf{o}}$ & $37 \mathrm{C}^{\mathbf{0}}$ \\
\hline \multirow[t]{6}{*}{3} & 10 & 7.5 & 9.2 & 11.8 & 14.4 \\
\hline & 20 & 12.1 & 15.7 & 21.2 & 23.6 \\
\hline & 30 & 19.6 & 19.7 & 27.6 & 30.2 \\
\hline & 40 & 24.2 & 25.2 & 31.5 & 35.5 \\
\hline & 50 & 27.2 & 28.9 & 38.1 & 42.9 \\
\hline & 60 & 30.0 & 35.5 & 40.7 & 47.3 \\
\hline \multirow[t]{6}{*}{5.7} & 10 & 7.7 & 10.6 & 14.4 & 17.5 \\
\hline & 20 & 13.3 & 17.0 & 21.6 & 26.9 \\
\hline & 30 & 20.0 & 21.2 & 27.8 & 35.6 \\
\hline & 40 & 24.4 & 28.7 & 37.1 & 44.0 \\
\hline & 50 & 27.8 & 37.2 & 46.7 & 51.7 \\
\hline & 60 & 33.0 & 41.4 & 50.0 & 55.2 \\
\hline \multirow[t]{6}{*}{7} & 10 & 8.7 & 11.4 & 19.6 & 23.4 \\
\hline & 20 & 12.0 & 17.7 & 30.0 & 35.2 \\
\hline & 30 & 17.5 & 23.9 & 42.7 & 43.7 \\
\hline & 40 & 26.3 & 31.2 & 46.3 & 49.5 \\
\hline & 50 & 30.7 & 36.4 & 52.2 & 56.7 \\
\hline & 60 & 34.6 & 42.7 & 56.8 & 60.3 \\
\hline \multirow[t]{6}{*}{9} & 10 & 10.1 & 16.8 & 26.2 & 29.2 \\
\hline & 20 & 13.7 & 20.6 & 41.4 & 48.7 \\
\hline & 30 & 19.5 & 26.4 & 49.6 & 57.4 \\
\hline & 40 & 26.5 & 32.1 & 55.3 & 62.3 \\
\hline & 50 & 32.1 & 39.3 & 63.2 & 71.1 \\
\hline & 60 & 36.7 & 45.9 & 69.6 & 77.6 \\
\hline \multirow[t]{6}{*}{11} & 10 & 10.4 & 18.5 & 40.7 & 48.2 \\
\hline & 20 & 15.6 & 23.2 & 50.1 & 55.9 \\
\hline & 30 & 20.8 & 27.6 & 57.4 & 66.7 \\
\hline & 40 & 28.1 & 34.2 & 64.2 & 72.1 \\
\hline & 50 & 35.4 & 40.6 & 77.8 & 83.4 \\
\hline & 60 & 39.5 & 47.5 & 85.1 & 92.6 \\
\hline
\end{tabular}

Application of kinetic laws on the decay of organic peroxides materials indicated that, the decay follow the first order kinetic model, which expressed as in the equation:

$\ln \mathrm{a} / \mathrm{a}-\mathrm{x}=\mathrm{k} \mathrm{t}$

where $\mathrm{a}$ is considered as $100 \%$ of decay and (a-x) is the residual of amino acid at certain time $(\mathrm{t}), \mathrm{k}$ is the rate of decomposition. Figures (15) show that, the decomposition of threonine peroxides obey First order plots. The calculated rate constants values of decomposition at different $\mathrm{pH}, \mathrm{s}$ are listed in Table (3). 
Figure (1): The first order of the decomposition of threonine peroxide at $\mathbf{p H}=3$ and different temperatures.

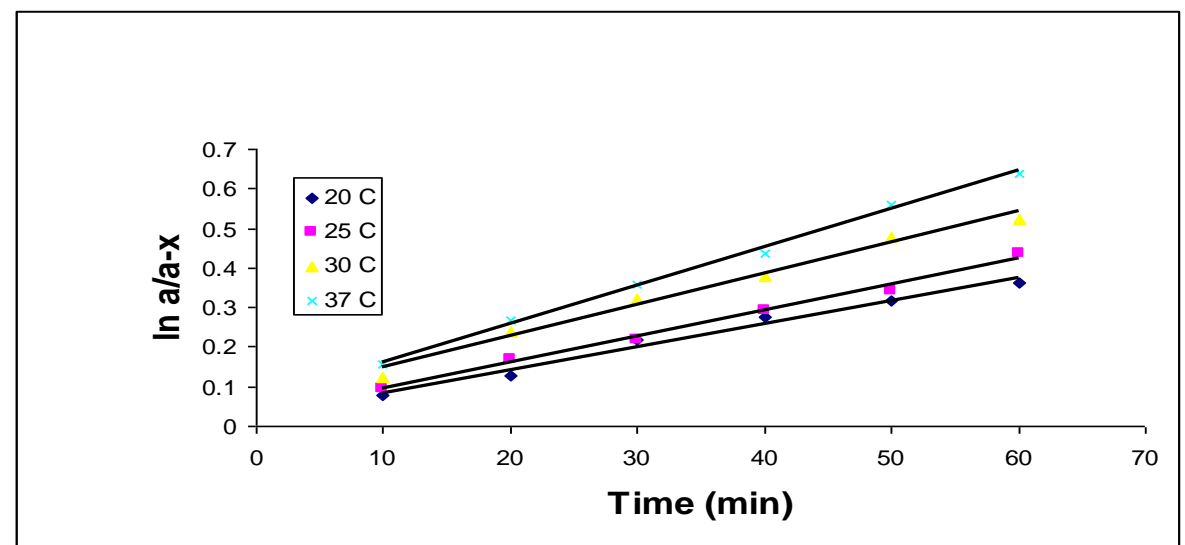

Figure (2): The first order of the decomposition of threonine peroxide at $\mathrm{pH}=5.7$ and different temperatures

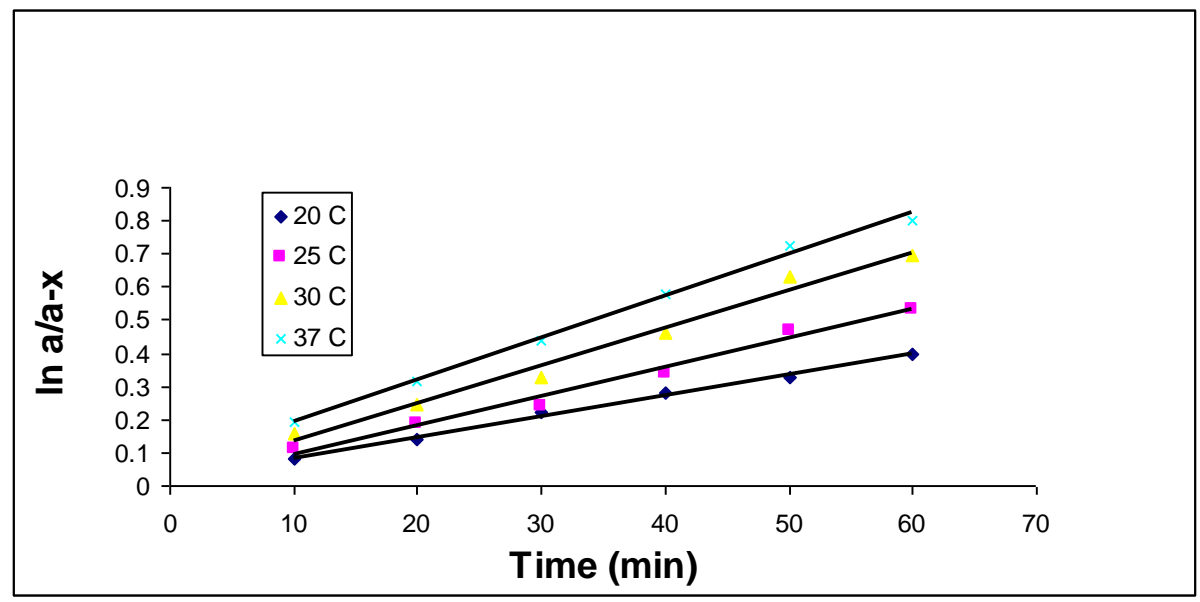

Figure (3): The first order of the decomposition of threonine peroxide at $\mathbf{p H}=7$ and different temperatures.

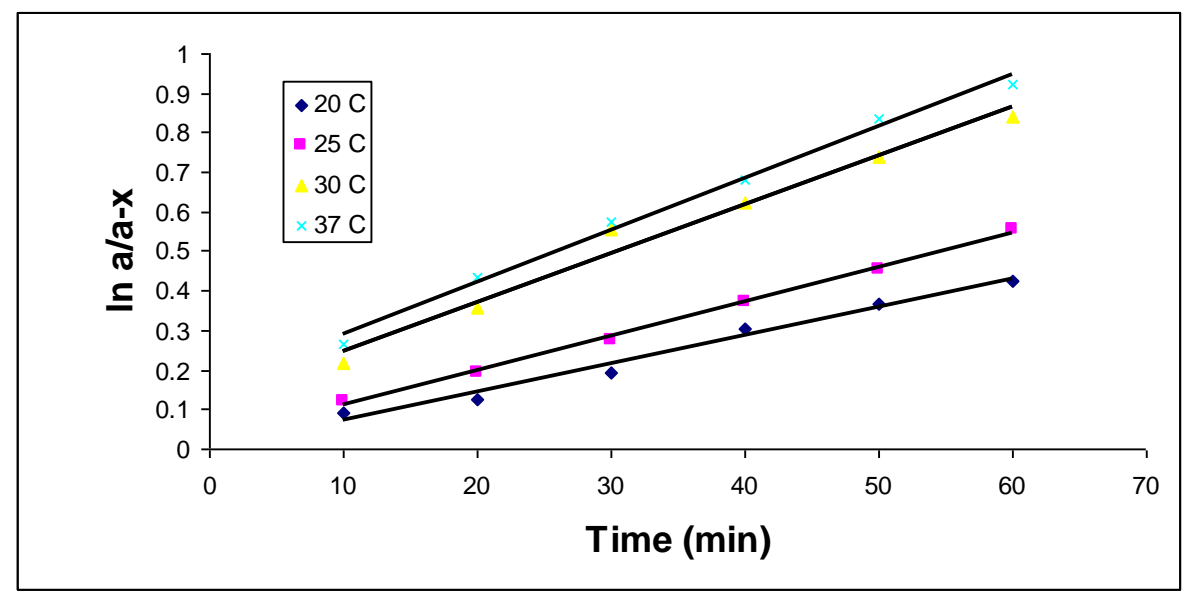


Kinetic and Activation Thermodynamic Studies on the Decay of Organic ...

Figure (4): The first order of the decomposition of threonine peroxide at $\mathbf{p H}=9$ and different temperatures.

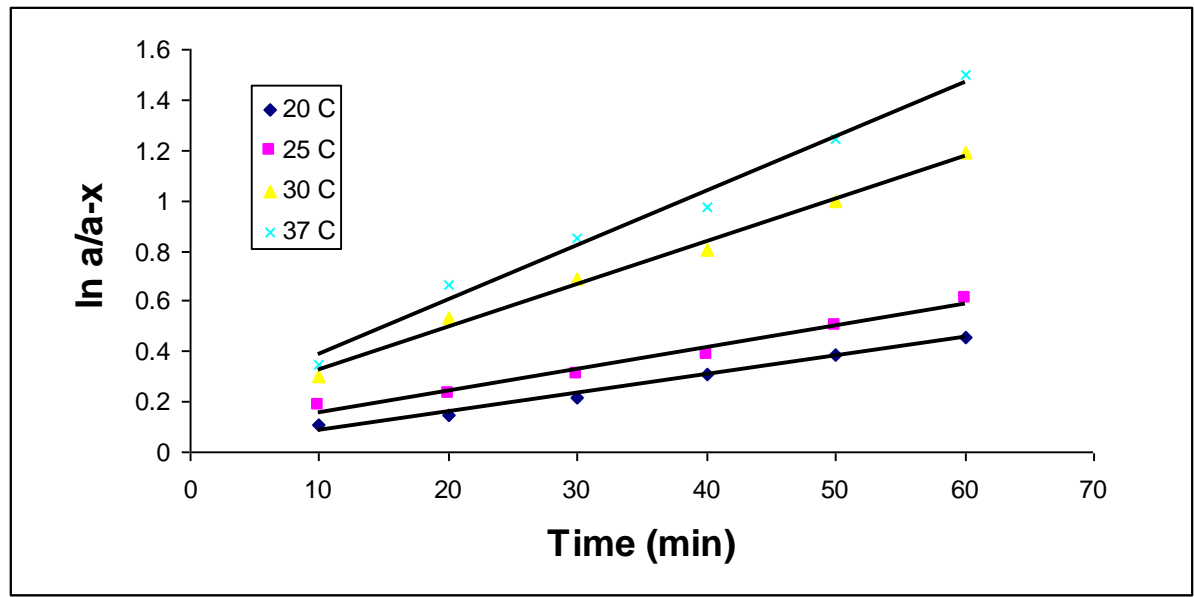

Figure (5): The first order of the decomposition of threonine peroxide at $\mathbf{p H}=11$ and different temperatures.

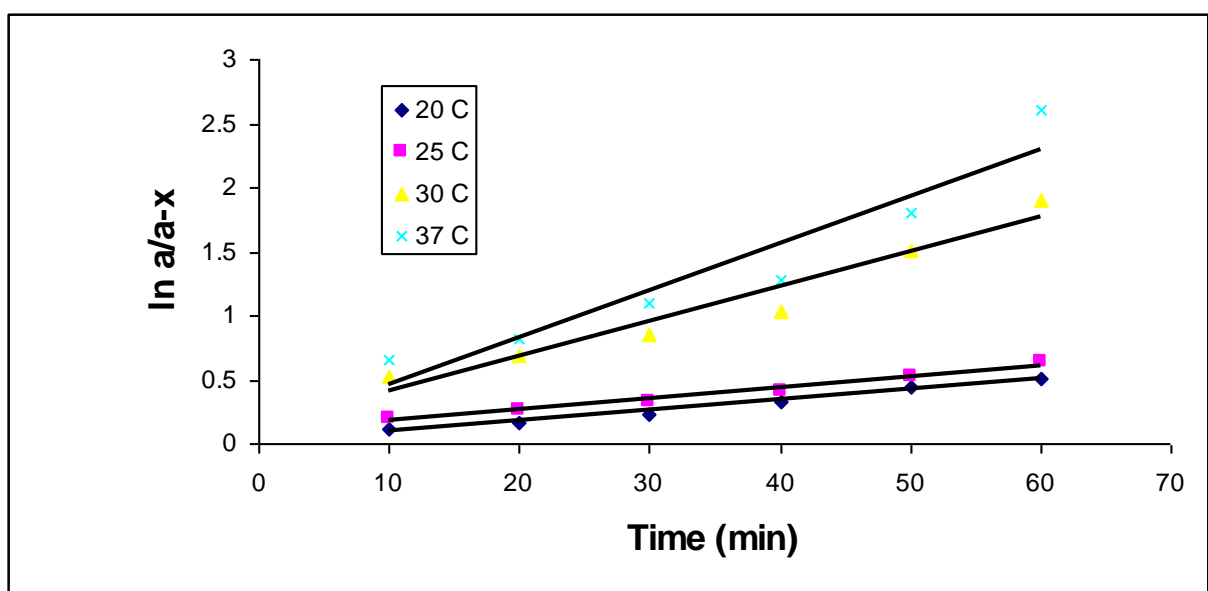

Table (3): The first order rate constants and $R^{2}$ values of the decomposition of oxygenated solutions of threonine organic peroxides at different $\mathrm{pH}$ 's and temperatures.

\begin{tabular}{|c|c|c|c|c|c|}
\hline \multirow[t]{2}{*}{ Temp $C^{o}$} & \multicolumn{5}{|c|}{ Rate constant $\left(\sec ^{-1}\right)$ at } \\
\hline & $\mathrm{pH}=3$ & $\mathrm{pH}=5.7$ & $\mathrm{pH}=7$ & $\mathrm{pH}=9$ & $\mathrm{pH}=11$ \\
\hline 20 & $\begin{array}{l}1.066 \times 10^{-4} \\
(0.9826)^{*}\end{array}$ & $\begin{array}{c}1.133 \times 10^{-4} \\
(0.9929)\end{array}$ & $\begin{array}{c}1.200 \times 10^{-4} \\
(0.9893)\end{array}$ & $\begin{array}{r}1.266 \times 10^{-4} \\
(0.9930)\end{array}$ & $\begin{array}{c}1.400 \times 10^{-4} \\
(0.9929)\end{array}$ \\
\hline 25 & $\begin{array}{c}1.200 \times 10^{-4} \\
(0.9873)\end{array}$ & $\begin{array}{c}1.483 \times 10^{-4} \\
(0.9903)\end{array}$ & $\begin{array}{c}1.550 \times 10^{-4} \\
(0.9955)\end{array}$ & $\begin{array}{c}1.700 \times 10^{-4} \\
(0.9683)\end{array}$ & $\begin{array}{c}1.800 \times 10^{-4} \\
(0.9551)\end{array}$ \\
\hline 30 & $\begin{array}{c}1.583 \times 10^{-4} \\
(0.9674)\end{array}$ & $\begin{array}{c}1.966 \times 10^{-4} \\
(0.9893)\end{array}$ & $\begin{array}{c}2.533 \times 10^{-4} \\
(0.9568)\end{array}$ & $\begin{array}{c}3.433 \times 10^{-4} \\
(0.9675)\end{array}$ & $\begin{array}{c}5.033 \times 10^{-4} \\
(0.9577)\end{array}$ \\
\hline 37 & $\begin{array}{c}1.866 \times 10^{-4} \\
(0.9817)\end{array}$ & $\begin{array}{c}2.366 \times 10^{-4} \\
(0.9873)\end{array}$ & $\begin{array}{c}2.800 \times 10^{-4} \\
(0.9505)\end{array}$ & $\begin{array}{c}4.266 \times 10^{-4} \\
(0.9716)\end{array}$ & $\begin{array}{c}6.466 \times 10^{-4} \\
(0.9404)\end{array}$ \\
\hline
\end{tabular}

* value of $\mathrm{R}^{2}$ 
The results show that, the rate constants of decomposition have increased by increasing $\mathrm{pH}$ of irradiated solutions. Effect of temperature was also been studied. The results obtained showed that, the decay of the peroxides is temperature dependent, since they have shown that, the decomposition increases by increasing temperature.

A conclusion drawn here, on the view of $\mathrm{pH}$ effect, that, the first step of decomposition is the deprotonation of peroxides molecules followed by other process. The $\mathrm{pH}$ effect indicates that,the peroxides produced on threonine amino acid in $\gamma$-irradiation of oxygenated solutions are of hydro organic peroxides (ROOH) type rather of (ROOR) where $\mathrm{R}$ and $\mathrm{R}$ represent threonine amino acid molecule with peroxide group at certain carbon atom.

The formation and decomposition of the observed organic peroxides is been predicted as in Scheme (1).

Scheme (1)

$$
\begin{array}{rllllll}
\mathrm{H}_{2} \mathrm{O} & \stackrel{\text { Ionisation }}{\underset{\text { Radiation }}{\longrightarrow}} & \mathrm{e}^{-} & \dot{\mathrm{H}} & \stackrel{\mathrm{OH}}{\mathrm{H}_{2}} & \mathrm{H}_{2} \mathrm{O}_{2} & \mathrm{H}_{3} \mathrm{O}^{+} \\
\mathrm{G} & 2.7 & 0.55 & 2.7 & 0.45 & 0.75 & 2.7
\end{array}
$$

The species $\mathrm{e}_{\text {aq }}^{-}$and $\mathrm{H} \cdot$ react very fast with molecular oxygen viz ${ }^{(13)}$ :

$$
\mathrm{e}^{-}{ }_{\mathrm{aq}}+\mathrm{O}_{2} \longrightarrow \mathrm{O}_{2}^{-}
$$

In acidic medium, the following reaction can occur:

$$
\mathrm{e}^{-}{ }_{\text {aq }}+\mathrm{H}^{+} \longrightarrow \mathrm{H}^{-}
$$

in a composition with reaction (2). Thus, the only active species under these conditions is the. $\mathrm{OH}$ radicals.

Threonine can be represented in general by $\mathrm{RH}$.

$$
\begin{aligned}
& \mathrm{RH}+\mathrm{OH} \longrightarrow \mathrm{R}+\mathrm{H}_{2} \mathrm{O} \\
& \mathrm{R}+\mathrm{O}_{2} \longrightarrow \mathrm{RO}_{2} \\
& \mathrm{RO}_{2}+\mathrm{HO}_{2} / \dot{\mathrm{O}}_{2}^{-} \underset{-\mathrm{OH}}{\stackrel{\mathrm{H}_{2} \mathrm{O}}{\longrightarrow}} \mathrm{RO}_{2} \mathrm{H}+\mathrm{O}_{2}
\end{aligned}
$$

The ionization of organic peroxide can be occurred by the following steps: 
This equation may represent the rate-determining step.

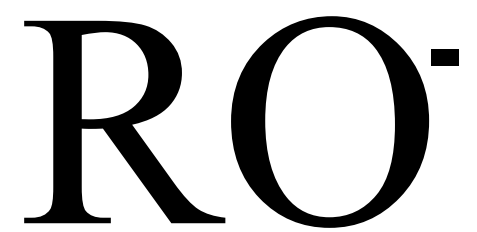

However, the observed decreases in organic peroxides give evidence that, the products in equations (10-12) almost not containing peroxides.

This work needs further studies involving the effect of $\mathrm{pH}$ on the decay of organic peroxides produced in irradiated solutions at different pH.This study will be the second part of this research.

The activation energies and thermodynamic parameters of activations have been calculated depending on the values of the decomposition rate constants listed in Table (3) which were determined at different temperature and $\mathrm{pH}^{\prime} \mathrm{s}$.

The Arrehenius equation used for the calculation of activation energy presented as:

$\ln \mathrm{k}=\ln \mathrm{A}-\mathrm{E} / \mathrm{RT}$

Where $\mathrm{A}$ is the frequency factor, $\mathrm{E}$ is the energy of activation, $\mathrm{R}$ is the gas constant $\left(8.314 \mathrm{~J} \cdot \mathrm{mol}^{-1} \cdot \mathrm{k}^{-1}\right)$ and $\mathrm{T}$ is the absolute temperature, The plot of $\ln \mathrm{k}$ versus $1 / \mathrm{T}$ gives a straight line of slope equal $\mathrm{E} / \mathrm{R}$ and intercept (ln $\mathrm{A}$ ). The value of $\Delta \mathrm{H}^{*}$ is calculated by the following equation:

$$
\Delta \mathrm{H}^{*}=\mathrm{E}-\mathrm{RT} \quad\left(\mathrm{J} \cdot \mathrm{mol}^{-1}\right)
$$

The entropy of activation $\Delta \mathrm{S}^{*}$ is been determined by the equation:

$$
\Delta \mathrm{S}^{*}=\mathrm{R}[\ln \mathrm{A}-\ln (\mathrm{KT} / \mathrm{h})-1] \quad\left(\mathrm{J}^{\mathrm{k}}{ }^{-1} \cdot \mathrm{ml}^{-1}\right)
$$

Where $\mathrm{K}$ is the Boltzmann constant $\left(1.38 \times 10^{-23} \mathrm{~J} \mathrm{~K}^{-1}\right), \mathrm{h}$ is the Plank constant $\left(6.626 \times 10^{-34} \mathrm{~J} . \mathrm{sec}\right)$ and A the frequency factor is determined in $\left(\sec ^{-1}\right)$.

The Free Gibbs of activation calculated by the equation:

$$
\Delta \mathrm{G}^{*}=\Delta \mathrm{H}^{*}-\mathrm{T} \Delta \mathrm{S}^{*}\left(\mathrm{~J} \cdot \mathrm{mol}^{-1}\right)
$$


The plots of $\mathrm{ln} \mathrm{k}$ at different $\mathrm{pH}$ s against $1 / \mathrm{T}$ gave the straight lines shown in Figure (6) with $\mathrm{R}^{2}$ range values of 0.89-0.96 and the calculated values of $\mathrm{E}, \Delta \mathrm{H}^{*}, \Delta \mathrm{G}^{*}$, and $\Delta \mathrm{S}^{*}$ are portrayed in Table (4).

Table (4): The thermodynamic parameters of activation of the decomposition of threonine at different $\mathrm{pH}$ 's.

\begin{tabular}{|c|c|c|c|c|c|}
\hline \multirow[t]{2}{*}{ pH } & \multirow{2}{*}{$\begin{array}{c}\mathbf{E} \\
\left(\mathrm{kJ} \cdot \mathrm{mol}^{-1}\right)\end{array}$} & \multicolumn{4}{|c|}{$\Delta \mathbf{H}^{*}\left(\mathrm{~kJ} . \mathrm{mol}^{-1}\right)$} \\
\hline & & $20^{\circ} \mathrm{C}$ & $25^{\circ} \mathrm{C}$ & $30^{\circ} \mathrm{C}$ & $37^{\circ} \mathrm{C}$ \\
\hline 3 & 26.099 & 23.663 & 23.621 & 23.580 & 23.521 \\
\hline 5.7 & 32.806 & 30.370 & 30.328 & 30.287 & 30.228 \\
\hline 7 & 39.410 & 36.974 & 36.932 & 36.890 & 36.832 \\
\hline 9 & 56.792 & 54.356 & 54.314 & 54.272 & 54.214 \\
\hline \multirow{3}{*}{11} & 73.312 & 70.876 & 70.835 & 70.793 & 70.735 \\
\hline & & \multicolumn{4}{|c|}{$\Delta G^{*}\left(\right.$ kJ.mol $\left.{ }^{-1}\right)$} \\
\hline & & $20^{\circ} \mathrm{C}$ & $25^{\circ} \mathrm{C}$ & $30^{\circ} \mathrm{C}$ & $37^{\circ} \mathrm{C}$ \\
\hline 3 & & 74.105 & 74.966 & 75.829 & 77.307 \\
\hline 5.7 & & 73.842 & 74.585 & 75.329 & 76.370 \\
\hline 7 & & 73.703 & 74.331 & 74.960 & 75.840 \\
\hline 9 & & 73.646 & 73.976 & 74.307 & 74.771 \\
\hline \multirow[t]{3}{*}{11} & & 73.515 & 73.560 & 73.607 & 73.637 \\
\hline & & \multicolumn{4}{|c|}{$\Delta \mathbf{S}^{*}\left(\mathbf{J} \cdot \mathbf{m o l}^{-1} \cdot \mathbf{K}^{-1}\right)$} \\
\hline & & $20^{\circ} \mathrm{C}$ & $25^{\circ} \mathrm{C}$ & $30^{\circ} \mathrm{C}$ & $37^{\circ} \mathrm{C}$ \\
\hline 3 & & -172.158 & -172.299 & -172.440 & -172.631 \\
\hline 5.7 & & -148.371 & -148.513 & -148.654 & -148.845 \\
\hline 7 & & -125.358 & -125.499 & -125.641 & -125.832 \\
\hline 9 & & -65.838 & -65.979 & -66.121 & -66.312 \\
\hline 11 & & -9.004 & -9.145 & -9.286 & -9.478 \\
\hline
\end{tabular}

Figure (6): The plot of in $k$ versus 1/T of the decomposition of oxygenated threonine solutions at different temperatures.

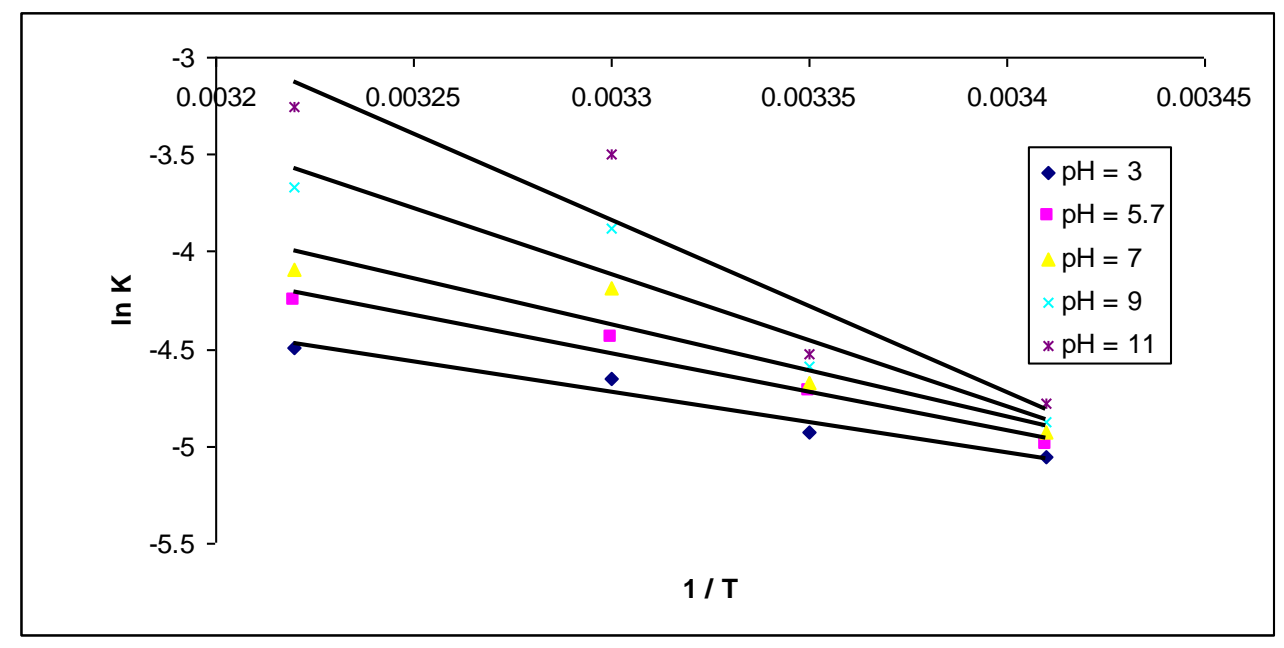


The results indicated clearly that, all values in general are consistent with the conditions of research. Positive values of $\Delta \mathrm{G}^{*}$ represent the non- spontaneously process of the activated complex formation. In other word, it can be easily concluded here, that, the postirradiation effect is temperature dependent. i.e., the temperature is one of the important factors govern the amount of damage induced by irradiation in a given time. Here, it can be concluded that, the effect of irradiation in the presence of oxygen increases by increasing temperature.

The results also give an idea that, $\mathrm{pH}$ has also significant effect on the net results of radiation damage.

Since, the results in Table (4) show important change in values in alkaline medium as compared with those obtained at other $\mathrm{pH}$ 's. The big difference is may be due to high ionization that occurs in amino acid involving the carboxylic and amino groups in addition to the hydroxyl group, which caused to obtain sharp differences in the values of the reported thermodynamic parameters.

\section{References}

1) W. Bennett and W. M. Garrison, Nature, 183, 889 (1959).

2) W. M. Garrison, Radiat. Res. Suppl.,4, 158 (1964).

3) M. Burton and J. L. Magee, (1972). "Advances in radiation chemistry", Vol. 3, USA, p133.

4) G. G. Jayson, G. Scholes and J. Weiss, "Formation of formylkynurenine by the action of X-Rays on Tryptophan in aqueous solutions", Biochem. J., 57, 386, (1954).

5) R. G. Armstrong and A. G. Swallow," Pulse and gamma radiolysis of aqueous solutions of Tryptophan", Radiation Res., 40, 563 (1969).

6) S. Abramovitch and J. Rabani, "Pulse radiolytic investigations of peroxy radicals in aqueous solutions of acetate and glycine", J. Phys. Chem., 80, 1562, (1976).

7) P. Makis and Al-Tappel, "Products of $\gamma$-irradiation of cysteine and cystine", J. Amer. Chem. Soc., 82,1613,(1960).

8) A. M. Hilme, "Gamma radiolysis of some amino acid in aqueous solutions", M. Sc Thesis, University of Mosul. Mosul-Iraq (2000).

9) I. M. AL-Giheshy, "Effect of gamma radiolysis of lysine and tyrosine in aqueous solutions", M. Sc Thesis University of Mosul, Mosul-Iraq (2002).

10) A. O. Allen, C. J. Hochanadel, J. A. Ghormley, and T. W. Davis, J. Phys. Chem.56, 573(1952).

11) D. Barham and P. Trinder, Analyst, 97, 142(1972).

12) Rana H. A. K. AL-Hyali, "Study of gamma radiolysis of threonine amino acid in aqueous solutions", M.Sc. Thesis, University of Mosul, Mosul-Iraq (2005).

13) G. J. Scheles, Radiology, 56, 221(1983). 